\title{
Strategi peningkatan pendapatan petani padi di Kecamatan Gunung Tujuh Kabupaten Kerinci
}

\author{
Utari Seplida*;Syamsurijal Tan;Yulmardi
}

\author{
Prodi Magister Ilmu Ekonomi Program Pascasarjana Universitas Jambi \\ *E-mail. korespondesi : utari.seplida@gmail.com
}

\begin{abstract}
This study aims to: (1) determine the socio-economic characteristics of rice farmers in Gunung Tujuh District, Kerinci Regency (2) to determine what factors affect the income of rice farmers in Gunung Tujuh Subdistrict, Kerinci Regency (3) to determine strategies for increasing income rice farmers in Gunung Tujuh District, Kerinci Regency. The quantitative analysis used in this research is regression analysis. Based on the results of multiple regressions, working capital variables, land area, and total production have positive and significant coefficients on farmers' income, where the amount of production variable is the variable that has the greatest influence on the income of rice farmers in Gunung Tujuh District, Kerinci Regency. The results of this study in the form of a strategy to increase rice farmers' income based on internal and external results showed that the main strategy is the strategic focus that must be done, namely optimizing weaknesses and overcoming various threats by reducing land conversion by providing capital, reactivating Gapoktan, optimizing fertilizer use, overcoming the problem of increasing input prices to increase cooperation between extension workers and Gapoktan in Gunung Tujuh District, Kerinci Regency.
\end{abstract}

Keywords: Strategies farmer's income, Education, Production, Capital costs

\begin{abstract}
Abstrak
Penelitian ini bertujuan untuk : (1) untuk mengetahui karakteristik sosial ekonomi petani padi di Kecamatan Gunung Tujuh Kabupaten Kerinci (2) untuk mengetahui faktor-faktor apa saja yang mempengaruhi pendapatan petani padi di Kecamatan Gunung Tujuh Kabupaten Kerinci (3) untuk mengetahui strategi peningkatan pendapatan petani padi di Kecamatan Gunung Tujuh Kabupaten Kerinci. Analisis kuantitatif yang digunakan dalam penelitian ini adalah analisis regresi. Berdasarkan hasil regresi berganda variabel modal kerja, luas lahan dan jumlah produksi memiliki koefisien positif dan signifikan terhadap pendapatan petani dimana variabel jumlah produksi merupakan variabel yang memiliki pengaruh paling besa $r$ terhadap pendapatan petani padi di Kecamatan Gunung Tujuh Kabupaten Kerinci. Hasil penelitian ini berupa strategi peningkatan pendapatan petani padi berdasarkan hasil internal dan eksternal diperoleh bahwa yang menjadi stratgei utama adalah fokus strategi yang harus dilakukan yaitu mengoptimalkan kelemahan dan mengatasi berbahgai ancaman dengan mengurangi alih fungsi lahan dengan memberikan modal, mengiatkan kembali Gapoktan, mengoptimalkan penggunaan pupuk, mengatasi persoalan kenaikan harga input meningkatkan kerja sama antara penyuluh dengan gapoktan di Kecamatan Gunung Tujuh Kabupaten Kerinci.
\end{abstract}

Kata kunci : Strategi pendapatan petani, Pendidikan, Produksi, Biaya modal 


\section{PENDAHULUAN}

Negara Indonesia merupakan negara agraris, dimana sumber mata pencaharian utama masyarakatnya adalah di bidang pertanian. Hal ini dilatar belakangi oleh letak geografis Indonesia yang berada di daerah tropis, sehingga keadaan cuaca, tanah dan sumber daya lainnya di setiap daerah di Indonesia memiliki potensi yang tinggi untuk dapat mengembangkan sektor pertanian. Pendayagunaan sumber daya pertanian menjadi kunci dalam meningkatkan produktivitas pertanian sehingga sumber daya yang terbatas itu harus dialokasikan seefisien mungkin.

Indonesia merupakan negara yang sedang melaksanakan pembangunan disegala bidang, sektor pertanian merupakan salah satu sektor yang diandalkan, karena sektor pertanian sampai saat ini masih memegang peranan penting dalam menunjang perekonomian nasional. Sektor pertanian juga mempunyai peranan penting dalam mengentaskan kemiskinan, pembangunan pertanian berkaitan baik secara langsung maupun tidak langsung dengan upaya peningkatan kesejahteraan petani dan upaya menanggulangi kemiskinan khususnya didaerah pedesaan.

Sebagai salah satu pilar ekonomi negara, sektor pertanian diharapkan dapat meningkatkan pendapatan terutama dari penduduk pedesaan yang masih di bawah garis kemiskinan. Untuk itu, berbagai investasi dan kebijakan telah dilakukan pemerintah untuk mendorong pertumbuhan di sektor pertanian. Investasi di sektor pertanian seringkali sangat mahal, ditambah lagi tingkat pengembaliannya sangat rendah dan waktu investasinya juga panjang sehingga tidak terlalu menarik swasta. pembangunan irigasi, penyuluhan pertanian dan berbagai bentuk investasi dalam bentuk subsidi dan lainnya pada umumnya harus dilakukan oleh pemerintah.

Salah satu wilayah yang dikenal dengan lumbung berasnya adalah Kabupaten kerinci yang terletak di Provinsi Jambi. Pertanian padi menjadi tanaman pokok di Kabupaten Kerinci. Hal ini dikarenakan tanaman ini dianggap dapat memberikan nilai tambah yang lebih bila dibandingkan dengan tanaman lain di Kabupaten Kerinci. Ini terlihat dengan sebagian besar areal pertanian di Kabupaten Kerinci digunakan untuk menanam padi. Mencukupi kebutuhan padi di Kabupaten Kerinci dan peningkatan kesejahteraan serta pendapatan petani merupakan tujuan yang hendak dicapai pemerintah setempat. Oleh sebab itu untuk mengurangi ketergantungan akan impor sangatlah diperlukan upaya untuk mempercepat peningkatan produksi padi sekaligus meningkatkan pendapatan petani. Kabupaten Kerinci, sektor pertanian sangat penting peranannya sebagai sumber pendapatan yang utama bagi masyarakat petani, umumnya para petani memproduksi hasil pertanian untuk memenuhi kebutuhan hidup sehari-harinya.Pendapatan petani saat ini merupakan masalah yang sangat serius karena banyak penduduk yang tinggal di desa bergerak disektor pertanian. Pendapatan petani yang berasal dari hasil produksi pertanian diolah oleh para petani.

Berdasarkan Tabel 1 menunjukkan bahwa Kecamatan Gunung Tujuh merupakan salah satu Kecamatan yang berada di Kabupaten Kerinci dan merupakan salah satunya daerah yang sangat berpotensi dalam swasembada pangan. Berdasarkan sumber BPS Kabupaten Kerinci, luas lahan padi sawah di Kecamatan tersebut mencapai 1.255,14 Ha dan hampir sebagian besar penduduk di Kecamatan Gunung Tujuh bermata pencaharian sebagai petani 
Tabel 1. Luas lahan dan produksi padi di Kecamatan Gunung Tujuh Kabupaten Kerinci

\begin{tabular}{clccc}
\hline NO & Kecamatan & Jumlah Desa & Luas Lahan (Ha) & Produksi (Ton) \\
\hline 1 & Air Hangat & 16 & 574,12 & 113,39 \\
2 & Air Hangat Barat & 12 & 443,2 & 881,7 \\
3 & Air Hangat Timur & 25 & $1.150,66$ & 145,22 \\
4 & Batang Merangin & 9 & 473,8 & 865,5 \\
5 & Bukit Kerman & 15 & 667,19 & 985,3 \\
6 & Danau Kerinci & 19 & $1.181,82$ & 128,67 \\
7 & Depati Tujuh & 20 & 788,49 & 137,89 \\
8 & Gunung Kerinci & 16 & 748,19 & 105,24 \\
9 & Gunung Raya & 12 & 496,58 & 470,6 \\
10 & Gunung Tujuh & 13 & $1.255,14$ & 147,67 \\
11 & Kayu Aro & 21 & $1.137,27$ & 583,0 \\
12 & Kayu Aro Barat & 17 & 55,31 & 26,0 \\
13 & Keliling Danau & 32 & $1.297,24$ & 165,31 \\
14 & Sitinjau Laut & 20 & $1.627,70$ & 176,12 \\
15 & Siulak & 26 & 665,55 & 108,67 \\
16 & Siulak Mukai & 14 & 742,37 & 352,9 \\
\hline & Total & $\mathbf{2 8 7}$ & $\mathbf{1 3 . 3 0 4 , 6 1}$ & $\mathbf{1 6 4 6 6 8}$ \\
\hline
\end{tabular}

Sumber : Kabupaten Kerinci Dalam Angka 2018(diolah)

\section{METODE}

Penelitian ini dilakukan di Kecamatan Gunung Tujuh Kabupaten Kerinci. Penentuan lokasi penelitian didasarkan atas pertimbangan bahwa Kecamatan Gunung Tujuh yang berada di Kabupaten Kerinci merupakan salah satu daerah yang sangat berpotensi dalam swasembada pangan dan hampir sebagian besar penduduk di Kecamatan Gunung Tujuh bermata pencarian sebagai petani.Objek penelitian dalam penelitian ini adalah petani padi di Kecamatan Gunung Tujuh Kabupaten Kerinci yang di kelompokan berdasarkan karateristik responden dan faktor-faktor yang mempengaruhinya, penelitian ini di lakukan di Kecamtan Gunung tujuh Kabupaten Kerinci.

Jenis data yang digunakan dalam penelitian ini adalah data primer Penelitian ini dilaksanakan dengan teknik survei. Dalam survei, informasi dikumpulkan dari responden dengan menggunakan kuisioner. Umumnya pengertian survei dibatasi pada penelitian yang datanya dikumpulkan dari sampel atas populasi untuk mewakili seluruh populasi. Dengan demikian penelitian survei adalah penelitian yang mengambil sampel dari satu populasi dan menggunakan kuisioner sebagai pengumpulan data yang pokok. Survei dilakukan dengan menggunakan kuesioner yang merupakan daftar pertanyaan terstruktur yang diajukan kepada petani padi sawah di Kecamatan Gunung Tujuh Kabupaten Kerinci.

\section{Populasi dan sampel}

Populasi yang disajikan sebagi objek penelitian ini adalah petani padi sawah di Kecamatan Gunung Tujuh Kabupaten Kerinci. Sampel adalah sebagian atau wakil populasi 
yang diteliti (Suharsimi, 2006). Untuk memperoleh sampel yang representatif, pengambilan subjek dari wilayah ditentukan seimbang atau sebanding dengan banyaknya subjek dalam masing-masing wilayah. Sampel yang ditetapkan dengan menggunakan metode Proporsional Area Random Sampling yaitu pengambilan sampel berdasarkan wilayah dimana masing-masing bagian terambil sampelnya secara acak. Penentuan sampel dengan menggunakan rumus Slovin.

Perhitunganya adalah:

$$
n=\frac{\mathrm{N}}{1+\mathrm{Ne} 2}
$$

$$
\begin{aligned}
& \mathrm{n}=6850 /\left(1+\left(6850 \times 0,1^{2}\right)\right) \\
& \mathrm{n}=6850 /(1+(6850 \times 0,01) \\
& \mathrm{n}=6850 /(1+68,5) \\
& \mathrm{n}=6850 / 69,5 \\
& \mathrm{n}=98,56
\end{aligned}
$$

Berdasarkan perhitungan menggunakan metode slovin, sampel yang akan digunakan dalam penelitian ini sebanyak 99 petani padi sawah.

\section{Metode analisis}

Dalam rangka menganalisis data yang telah terkumpul guna menguji hipotesis yang telah dirumuskan, maka digunakan metode analisis Deskriptif dan metode analisis kuantitatif

\section{Analisis deskriptif}

Untuk menjawab permasalahan pertama tentang karakteristik sosial ekonomi petani padi akan dilakukan dengan analisis deskriptif yaitu berupa pemamparan atau pengambaran dengan kata-kata secara jelas dan terperinci (KKBI,2001).

\section{Analisis kuantitatif}

Dalam menjawab pemasalahan kedua, penulis menggunakan analis kuantitatif Analisis Regresi Linear Berganda. Secara umum analisis regresi ialah analisis yang dilakukan untuk mengetahui pengaruh hubungan variabel bebas (indipenden) terhadap variabel terikat (dependen), Luas lahan, Biaya Modal, Tingkat Pendidikan, Jumlah Produksi, secara matematis ditulis.

\section{TRD =f $(\mathbf{J T}, \mathbf{P}, \mathbf{L L}, \mathbf{Q}, \mathbf{B M}, \mathbf{Q}, \mathrm{e})$}

Secara explisit dapat dinyatakan sebagai berikut:

\section{$\log T R D=\beta_{0}+\beta_{1} J T L o g+\beta_{2} P \log +\beta_{3} \operatorname{LLlog}+\beta_{4} Q \log +\beta_{5} B M l o g+e$}

Keterangan:

$$
\begin{array}{ll}
\text { TRD } & =\text { Pendapatan petani padi } \\
\text { JT } & =\text { Jumlah Tangunggan } \\
\mathrm{P} & =\text { Pendidikan } \\
\text { LL } & =\text { Luas Lahan } \\
\mathrm{Q} & =\text { Jumlah Produksi } \\
\mathrm{BM} & =\text { Biaya Modal } \\
\mathrm{e} & =\text { Faktor Penganggu }
\end{array}
$$


Analisis regresi pada dasarnya adalah studi ketergantungan variable dependen (terikat) dengan satu atau lebih variabel independen (variabel penjelas/bebas), dengan tujuan untuk mengestimasi dan/atau memprediksi rata-rata populasi atau nilai rata-rata variabel dependen berdasarkan nilai variabel independen yang diketahui.

\section{Pengujian statistik}

Ketepatan fungsi regresi sampel dalam menaksir nilai aktual dapat diukur dari goodness of fit-nya. Secara statistik, setidaknya ini dapat diukur dari nilai: koefisien deterministic, Nilai statistik F, Nilai statistik t.

\section{Uji F-statistik}

Uji F digunakan untuk menguji hipotesis nol bahwa koefisien determinasi mejemuk dalam populasi, $\mathrm{R}^{2}$ sama dengan nol. Uji signifikan meliputi pengujian signifikan persamaan regresi secara keseluruhan serta koefisien regresi parsial spesifik. Uji keseluruhan dapat dilakukan dengan menggunakan statistic F.

\section{Uji t-statistik}

Uji-t adalah jenis pengujian statistik untuk mengetahui apakah ada perbedaan dari nilai yang diperkirakan dengan nilai hasil perhitungan statistik. Uji $t$ pada dasarnya menunjukan seberapa jauh pengaruh satu variabel bebas secara individual dalam menerangkan variasi terikat.

\section{Koefisien determinasi}

Uji koefisien determinasi digunakan untuk mengukur seberapa besar presentase variasi variabel bebas (independen) pada model regeresi linier berganda dalam menjelaskan variabel terikat (dependen) (Priyantno,2008). Nilai koefisien determinasi adalah antara nol dan satu. Nilai $\mathrm{R}^{2}$ yang kecil bearti kemampuan variabel-variabel iondependen dalam menjelasakn variabel dependepn amat terbatas.

\section{Analisis SWOT}

Untuk menjawab tujuan penelitian ketiga yaitu menganalisis strategi Peningkatan Pendapatan Petani Padi Sawah di Kecamatan Gunung Tujuh Kabupaten Kerinci, digunakan analisis strategi SWOT. Analisis SWOT didasarkan pada logika, yaitu memaksimalkan kekuatan (Strengths) dan peluang (Opportunities), namun secara bersamaan dapat meminimalkan kelemahan (Weaknesses) dan ancaman (Threat).

\section{HASIL DAN PEMBAHASAN}

\section{Karakteristik sosial ekonomi petani padi di Kecamatan Gunung Tujuh Kabupaten Kerinci.}

Karaktersistik Sosial Petani Padi yang ditanyakan yaitu meliputi umur, jumlah anak, jumlah tanggungan, tingkat pendidikan, sementara karakteristik ekonominya yaitu luas lahan, modal kerja, jumlah produksi dan pendapatan. Berdasarkan penelitian yang peneliti lakukan dapat dideskripsikan sebagai berikut

\section{Karaktersitik responden berdasarkan umur}

Sebelum mengetahui karakteristik respondn berdasarkan umum, terlebih dahulu dilakukan perhitungan skala interval umur dengan umur responden termuda yaitu 23 tahun 
dan umur responden paling tua berumur 63 tahun. Rangge dari 23 tahun ke 63 adalah 40 tahun. Jika di penelitian ini menggunakan 6 kali interval. Artinya jarak interval katagori umur responden adalah 6 tahun.

Tabel 2. Karakteristik responden berdasarkan umur

\begin{tabular}{cccc}
\hline No & Umur & Frekuensi & Persentase (\%) \\
\hline 1 & $23-29$ & 13 & 13,14 \\
2 & $30-36$ & 10 & 10,11 \\
3 & $37-42$ & 29 & 29,30 \\
4 & $43-49$ & 27 & 27,28 \\
5 & $50-56$ & 14 & 14,14 \\
6 & $57-63$ & 6 & 6,06 \\
\hline \multicolumn{5}{r}{ Jumlah } & $\mathbf{1 0 0 , 0 0}$
\end{tabular}

Sumber : Data diolah,2020

Dari Tabel 2 diatas dapat dikatakan bahwa rata-rata umur petani padi berkisaran 3742 tahun, di umur ini dapat dikatakan sangat efektif dan efisien untuk mencari penghasilan dan dimana pada masa ini seseorang telah mempunyai banyak penghasilan dan dimana pada masa ini seseorang telah mempunyai banyak pengalaman sehingga dapat mengatasi masalah-masalah yang muncul. Sementara untuk petani padi yang berusia 57-63 tahun sejumlah 6 orang dikarenakan pada umur ini petani pada sudah mulai termakan oleh usia dan tidak mampu untuk bekerja lebih keras lagi disebabkan oleh fisik yang sudah melemah.

\section{Karakteristik responden berdasarkan jumlah anak}

Banyaknya Responden dalam penelitian ini yaitu petani padi di Kecamatan Gunung Tujuh Kabupaten Kerinci menurut jumlah anak yang dapat dilihat pada tabel 3 berikut:

Tabel 3. Karkteristik responden berdasarkan jumlah anak

\begin{tabular}{cccc}
\hline No & Jumlah Anak & Frekuensi & Persentase (\%) \\
\hline 1 & Tidak Ada & 3 & 3,03 \\
2 & 1 & 15 & 15,15 \\
3 & 2 & 37 & 37,38 \\
4 & $>3$ & 44 & 44,44 \\
\hline & Jumlah & & $\mathbf{1 0 0 , 0 0}$
\end{tabular}

Sumber : Data diolah,2020

Berdasarkan Tabel 3 diatas dapat dikatakan bahwa rata-rata jumlah anak petani padi berkisar 3 orang anak. Banyaknya jumlah anak petani disebabkan kurangnya pemahaman tentang Keluarga Berencana dikarenakan kurangnya penyuluhan dari pemerintah dalam program keluarga berencana sehingga masyarakat mempunyai anak lebih dari 3 anak. Dan ini membuktikan bahwa anak menjadi alasan petani untuk melakukan kegiatan berusaha kususnya dibidang pertanian agar mendapatkan penghasilan.

\section{Karakteristik responden berdasarkan jumlah tangunggan}

Banyaknya responden dalam penelitian ini yaitu petani padi di Kecamatan Gunung Tujuh Kabupaten Kerinci yang dapat dilihat pada Tabel 4 berikut: 
Tabel 4. Karakteristik responden berdasarkan jumlah tangunggan

\begin{tabular}{|c|c|c|c|}
\hline No & Jumlah Tangunggan & Frekuensi & Persentase $(\%)$ \\
\hline 1 & Tidak ada & 4 & 4,04 \\
\hline 2 & 1 & 16 & 16,16 \\
\hline 3 & 2 & 34 & 34,34 \\
\hline 4 & $>3$ & 45 & 45,46 \\
\hline \multicolumn{2}{|r|}{ Jumlah } & & 100,00 \\
\hline
\end{tabular}

Sumber : Data diolah,2020

Berdasarkan Tabel 4, dapat dikatakan bahwa rata-rata jumlah tangunggan petani padi berkisar 3 orang tanggungan. Besarnya jumlah tanggunggan akan meningkatkan motivasi petani padi untuk meningkatkan pendapatannya. Hal ini di dibuktikan jumlah responden terbanyak berdasarkan jumlah jumlah tanggungan adalah 3 orang atau lebih dengan responden sebanyak 45 orang sementara sebaliknya jumlah responden terendah berdasarkan jumlah tanggungan yaitu tidak adda tanggungan dengan jumlah responden sejumlah 4 orang.

\section{Karakteristik responden berdasarkan tingkat pendidikan}

Banyak responden dalam penelitian ini yaitu petani padi di Kecamatan Gunung Tujuh Kabupaten Kerinci menurut tingkat pendidikan dapat dilihat pada Tabel 5 berikut:

Tabel 5. Karakteristik responden berdasarkan tingkat pendidikan

\begin{tabular}{clcc}
\hline No & \multicolumn{1}{c}{ Tingkat Pendidikan } & Frekuensi & Persentase (\%) \\
\hline 1 & Sekolah Dasar & 25 & 25,26 \\
2 & Sekolah Menengah Pertama & 38 & 38,38 \\
3 & Sekolah Menengah Atas & 28 & 28,28 \\
4 & Diploma III-Strata I & 8 & 8,08 \\
\hline & Jumlah & & $\mathbf{1 0 0 , 0 0}$ \\
\hline
\end{tabular}

Sumber : Data diolah, 2020

Dilihat dari Tabel 5 dapat dikatakan bahwa rata-rata tingkat pendidikan petani padi yaitu tamatan Sekolah Menengah Pertama.Dilihat dari tingkat pendidikan yang ditamatkan oleh responden yang masih rendah tersebut, tentu berimplikasi pada proses produksi penanaman padi di Kecamatan Gunung Kerinci Kabupaten Kerinci. Dimana dalam teori sumber daya manusia menunjukan, bahwa semakin tinggi pendidikan seseorang, cenderung semakin tinggi produktivitasnya. Logikanya semakin tinggi penguasaan ilmu pengetahuan dan teknologi, cenderung semakin inovatif, yang akan membawa dampak positif pada pembangunan sektor pertanian, dengan produktivitas hasil pertanian yang semakin tinggi pula.

\section{Karaktersitik berdasarkan jumlah lahan}

Sebelum mengetahui karakteristik responden berdasarkan luas lahan, terlebih dahulu dilakukan perhitungan skala interval luas lahan dengan luas lahan responden dari 
$400 \mathrm{~m}^{3}$ sampai $2000 \mathrm{~m}^{3}$. Range dari $400 \mathrm{~m}^{3}$ sampai $2000 \mathrm{~m}^{3}$ adalah $1.600 \mathrm{~m}^{3}$. Jika di penelitian ini menggunakan 4 kali interval, maka jarak setiap interval $1.600 \mathrm{~m} 3: 4=400$. Artinya jarak interval katagori luas lahan adalah 400.

Tabel 6. Karakteristik responden berdasarkan luas lahan

\begin{tabular}{cccc}
\hline No & Luas Lahan & Frekuensi & Persentase (\%) \\
\hline 1 & $400 \mathrm{~m}^{3}-799 \mathrm{~m}^{3}$ & 33 & 33,34 \\
2 & $800 \mathrm{~m}^{3}-1299 \mathrm{~m}^{3}$ & 47 & 47,48 \\
3 & $1300 \mathrm{~m}^{3}-1699 \mathrm{~m}^{3}$ & 12 & 12,12 \\
4 & $1700 \mathrm{~m}^{3}-2000 \mathrm{~m}^{3}$ & 7 & 7,07 \\
\hline \multicolumn{2}{l}{ Jumlah } & & $\mathbf{1 0 0 , 0 0}$ \\
\hline
\end{tabular}

Sumber : Data diolah, 2020

Berdasarkan Tabel 6 diatas dapat dilihat bahwa rata-rata luas lahan 800-1200 $\mathrm{m}^{3}$. Didaerah peneliti tergolong memiliki lahan yang cukup produktif untuk melaksanakan kegiatan usahatani padi sawah berdasarkan hasil observasi dilapangan, dilihat dari banyaknya petani yang masih bertahan untuk tetap menanam padi sawah dilahan produktifnya, baik dari segi sebagai penghasilan utama maupun untuk kebutuhan tambahan penghasilan untuk memenuhi kebutuhan hidup keluarga, karena karakter lahan pertanian di Kabupaten Kerinci cocok untuk tanaman pertanian khusunya tanaman padi.

\section{Karakteristik responden berdasarkan jumlah produksi}

Sebelum mengetahui karakteristik responden berdasarkan jumlah produksi, terlebih dahulu dilakukan skala interval jumlah produksi dengan jumlah produksi dari responden dari yang terkecil yaitu $300 \mathrm{Kg}$ sampai $1800 \mathrm{~kg}$ dengan range dari $300 \mathrm{~kg}$ ke $1800 \mathrm{~kg}$ adalah $1500 \mathrm{~kg}$. jika di penelitian ini mengunakan 3 kali interval, maka jarak setiap interval adalah 1500:3 = $500 \mathrm{~kg}$. artinya jarak interval katagori jumlah produksi responden adalah $500 \mathrm{~kg}$.

Tabel 7 karakteristik responden berdasarkan jumlah produksi

\begin{tabular}{cccc}
\hline No & Jumlah Produksi & Frekuensi & Persentase (\%) \\
\hline 1 & $300 \mathrm{~kg}-799 \mathrm{~kg}$ & 38 & 38,38 \\
2 & $800 \mathrm{~kg}-1299 \mathrm{~kg}$ & 45 & 45,46 \\
3 & $1300 \mathrm{~kg}-1800 \mathrm{~kg}$ & 16 & 16,16 \\
\hline & Jumlah & & $\mathbf{1 0 0 , 0 0}$ \\
\hline
\end{tabular}

Sumber : Data diolah, 2020

Berdasarkan Tabel 7, dapat dilihat bahwa rata-rata jumlah produksi petani padi di Kecamatan Gunung Tujuh Kabupaten Kerinci 800 kg-1200 kg dan hasil tersebut tersebut sesuai dengan luas lahan yang dimiliki petani. Jumlah produksi tersubut tentunya faktor yang paling penting untuk meningkatkan dan memaksimalakan pedapatan petani padi.

\section{Karakteristik responden berdasarkan biaya modal}

Sebelum mengetahui karakteristik responden berdasarkan biaya modal terlebih dahulu dilakukan skala interval biaya modal dengan biaya modal responden dari yang 
terkecil yaitu Rp.600.0000 sampai Rp. 6.000.0000 Range dari Rp.600.000 ke Rp. 6.000.000 adalah Rp. 5.400.000. Jika di penelitian ini mengunakan 3 kali interval, maka jarak setiap interval adalah 5.400.000:3 = Rp. 1.800.000. Artinya jarak interval katagori Biaya modal responden adalah Rp. 1.800.000.

Tabel 8. Karakteristik responden berdasarkan biaya modal

\begin{tabular}{clcc}
\hline NO & \multicolumn{1}{c}{ Modal kerja } & Frekuensi & Persentase (\%) \\
\hline 1 & Rp. 600.000-Rp. 2.399.000 & 37 & 37,38 \\
2 & RP. 2.400.000-Rp. 4.199.000 & 46 & 46,46 \\
3 & Rp.4.200.000-Rp. 6.000.000 & 16 & 16,16 \\
\hline \multicolumn{2}{c}{ Jumlah } & & $\mathbf{1 0 0 , 0 0}$ \\
\hline
\end{tabular}

Sumber : Data diolah, 2020

Biaya modal yang digunakan petani dari 99 orang responden di Kecamatan Gunung Tujuh Kabupaten Kerinci disajikan pada Tabel 8 dapat dilihat bahwa petani padi di Kecamatan Gunung Tujuh Kabupaten Kerinci yang biaya modal berkisar 600.0002.300.000 sebanyak 37 orang petani padi dengan persentase sebesar 37,38 persen, kemudian jumlah petani padi yang biaya modal diantara Rp. 2.400 .000 sampai Rp. 4.100.000 sebanyak 46 orang petani padi dengan persentase 46,46 persen. Sedangkan biaya modal berkisar 16 orang petani padi dengan persentase 16,16 persen.

\section{Karakteritik responden berdasarkan pendapatan}

Sebelum mengetahui karakteristik responden berdasarkan pendapatan terlebih dahulu dilakukan perhitungan skala interval pendapatan dengan pendapatan responden dari yang terkecil Rp. 3.000.000 sampai Rp.14.000.0000. Range dari Rp.3.000.000 ke Rp.14.000.000 adalah Rp.11.000.000. Jika di penelitian ini menggunakan 4 kali interval, maka jarak setiap interval Rp. 11.000.000:4 = Rp. 2.750.000. Artinya jarak interval katagori pendapatan responden adalah Rp. 2.750.000.

Tabel 9. Karakteristik responden berdasarkan pendapatan

\begin{tabular}{cccc}
\hline No & \multicolumn{1}{c}{ Modal kerja } & Frekuensi & Persentase(\%) \\
\hline 1 & Rp.3.000.000-Rp.5.749.000 & 21 & 21,22 \\
2 & Rp.5.750.000-Rp.8.599.000 & 28 & 28,28 \\
3 & Rp.8.500.000-Rp.11.249.000 & 37 & 37,37 \\
4 & Rp.11.250.000-Rp.14.000.000 & 13 & 13,13 \\
\hline \multicolumn{2}{c}{ Jumlah } & & $\mathbf{1 0 0 , 0 0}$ \\
\hline
\end{tabular}

Sumber : Data diolah, 2020

Petani padi dengan jumlah paling banyak yaitu pendapatan yang berkisar Rp. 8.500.000 sampai Rp. 11.250.000 persekali panen dengan jumlah 37 orang. Pendapatan persekali panen petani padi dapat dikatakan tergolong cukup sejahtera petani padi sudah bisa menghidupi keluarga yang mereka tanggung. 


\section{Hasil regresi}

Metode Dasar yang digunakan untuk menjawab rumusan masalah yang kedua dengan model regresi linier berganda. Data diolah dan diregres menggunakan software eviews 8 , sehingga di dapatlah hasil estimasi sebagai berikut

$\log ($ TRD $)=10,237+0,002 \operatorname{Lof}(J T)-0,001 \log (p)+0,079 \log (L L)+0,820 \log (Q)-0,024 \log (B M)+e$

Persamaan regresi tersebut dapat dijelaskan sebagai berikut, Konstan 10,22519 artinya apabila variabel jumlah tangunggan, pendidikan, luas lahan, jumlah produksi, dan biaya modal tetap atau tidak berubah, maka variabel pendapatan akan naik sebesar 10,22519 persen.

Koefisien jumlah tangunggan $\left(\mathrm{X}_{1}\right)$ adalah 0.002943 artinya jika variabel jumlah tangunggan mengalami kenaikan sebesar satu persen, sementara pendidikan, luas lahan, jumlah produksi dan biaya modal dianggap tetap atau tidak berubah, maka akan menyebabkam kenaikan pendapatan petani padi sebesar 0.002943 Persen.

Koefisien pendidikan $\left(\mathrm{X}_{2}\right)$ adalah -0.001790 artinya jika variabel pendidikan mengalami kenaikan sebesar satu persen, sementara jumlah tangunggan, luas lahan, jumlah produksi dan biaya modal dianggap tetap atau tidak berubah, maka akan menurunkan pendapatan petani padi sebesar -0.001790 persen.

Koefisien Luas Lahan $\left(\mathrm{X}_{3}\right)$ adalah 0.079449 artinya jika variabel Luas Lahan mengalami kenaikan sebesar satu persen, sementara jumlah tangunggan, Pendidikan, jumlah produksi dan biaya modal dianggap tetap atau tidak berubah, maka akan menyebabkan kenaikan pendapatan petani padi sebesar 0.079449 persen.

Koefisien jumlah produksi $\left(\mathrm{X}_{4}\right)$ adalah 0.820542 artinya jika variabel jumlah produksi mengalami kenaikan sebesar satu persen, sementara jumlah tangunggan, Pendidikan, luas lahan dan biaya modal dianggap tetap atau tidak berubah, maka akan menyebabkan kenaikan pendapatan petani padi sebesar 0.820542 persen.

Koefisien biaya modal $\left(\mathrm{X}_{5}\right)$ adalah -0.024769 artinya jika variabel biaya modal mengalami kenaikan sebesar satu persen, sementara jumlah tangunggan, Pendidikan, luas lahan dan jumlah produksi dianggap tetap atau tidak berubah, maka akan menurunkan pendapatan petani padi sebesar -0.024769 persen.

\section{Pengujian statistik}

\section{Uji stastistik}

Uji $\mathrm{F}$ dilakukan untuk melihat pengaruh variable independen secara simultan terhadap variable dependen atau sering disebut uji kelinieran persamaan regresi. Hasil dari uji $\mathrm{F}$ pada penelitian ini diperoleh nilai sig $=0,000<0,05$ ini bearti variable independen jumlah tangunggan, pendidikan, luas lahan, jumlah produksi dan biaya modal secara simulutan benar-benar berpengaruh signifikan terhadap variable dependen pendapatan petani padi. Maka dengan kata lain variable-variabel. Maka dengan kata lain variablevariabel, jumlah tangunggan, pendidikan, luas lahan, jumlah produksi, biaya modal, mampu menjelaskan besarnya variable dependen pendapatan petani padi.

\section{Pengujian hipotesis secara parsial (uji t)}

Uji t dilakukan untuk memgetahui apakah secara individual (parsial) variable independen mempengaruhi variabel dependen secara signifikan atau tidak. Jika tingkat 
signifikannya dibawah 5\% maka secara persial jumlah tangunggan, pendidikan, luas lahan, jumlah produksi, biaya modal berpengaruh terhadap pendapatan petani padi.

Maka Dengan tingkat kepercayaan $=95 \%$ atau $(\alpha)=0,05$. Derajat kebebsan $(\mathrm{df})=$ $\mathrm{n}-\mathrm{k}-1=99-5-1=93$, serta pengujian dua sisi diperoleh dari nilai t $0,05=1.66140$. Pengaruh jumlah tangunggan terhadap pendapatan petani padi Dari hasil pengujian diperoleh nilai thitung untuk variabel jumlah tangunggan sebesar 0.543296 dengan tingkat keyakinan $(\alpha=$ $5 \%) \mathrm{df}=(93)$ untuk pengujian diperoleh nilai $t_{\text {tabel }} 1,1661$ dari perhitungan tersebut dapat dilihat bahwa nilai $t_{\text {hitung }}$ lebih kecil dari $t_{\text {tabel }}(0,543296<1,1661)$, artinya Ho diterima Ha ditolak artinya jumlah tangunggan tidak berpengaruh signifikan terhadap pendapatan petani padi di Kecamatan Gunung Tujuh Kabupaten Kerinci..

Pengaruh Pendidikan terhadap pendapatan petani padi Dari hasil pengujian diperolah nilai thitung untuk variabel pendidikan sebesar -1,009409 dengan tingkat keyakinan $(\alpha=5 \%) \mathrm{df}=(93)$ untuk pengujian diperoleh nilai $\mathrm{t}_{\text {tabel }} 1,1661$ dari perhitungan tersebut dapat dilihat bahwa nilai $t_{\text {hitung }}$ lebih kecil dari $t_{\text {tabel }}(-1,009409<1,1661)$, artinya Ho diterima Ha ditolak artinya pendidikan tidak berpengaruh signifikan terhadap pendapatan petani padi di Kecamatan Gunung Tujuh Kabupaten Kerinci.

Pengaruh luas lahan terhadap pendapatan petani padi. Dari hasil pengujian diperoleh nilai thitung untuk variabel luas lahan sebesar 2.963470 dengan tingkat keyakinan $(\alpha=5 \%) \mathrm{df}=(93)$ untuk pengujian diperoleh nilai $\mathrm{t}_{\text {tabel }} 1,1661$ dari perhitungan tersebut dapat dilihat bahwa nilai thitung lebih besar dari tabel $(2.963470>1,1661)$, artinya Ho ditolak Ha diterima artinya luas lahan berpengaruh signifikan dan positif terhadap pendapatan petani padi di Kecamatan Gunung Tujuh Kabupaten Kerinci.

Penggaruh jumlah produksi terhadap pendapatan petani padi.Dari hasil pengujian diperoleh nilai $t_{\text {hitung }}$ untuk variabel jumlah produksi sebesar 25.56124 dengan tingkat keyakinan $(\alpha=5 \%) \mathrm{df}=(93)$ untuk pengujian diperoleh nilai $t_{\text {tabel }} 1,1661$ dari perhitungan tersebut dapat dilihat bahwa nilai $t_{\text {hitung }}$ lebih besar dari $\mathrm{t}_{\text {tabel }}(25.56124>1,1661)$, artinya Ho ditolak Ha diterima artinya jumlah produksi berpengaruh signifikan dan positif terhadap pendapatan petani padi di Kecamatan Gunung Tujuh Kabupaten Kerinci.

Pengaruh biaya modal terhadap pendapatan petani padi. Dari hasil pengujian diperoleh nilai thitung untuk variabel jumlah tangunggan sebesar -1.979383 dengan tingkat keyakinan $(\alpha=5 \%) \mathrm{df}=(93)$ untuk pengujian diperoleh nilai $t_{\text {tabel }} 1,1661$ dari perhitungan tersebut dapat dilihat bahwa nilai $t_{\text {hitung }}$ lebih besar dari $t_{\text {tabel }}(-1.979383>1,1661)$, artinya Ho ditolak Ha diterima artinya biaya modal berpengaruh signifikan dan positif terhadap pendapatan petani padi di Kecamatan Gunung Tujuh Kabupaten Kerinci.

\section{Uji koefisien determinasi $\left(\mathbf{R}^{\mathbf{2}}\right)$}

Dari hasil perhitungan secara statistic dengan menggunakan EViews 8 diperoleh nilai koefisien determinasi $\mathrm{R}^{2}$ sebesar 0,94 atau $94 \%$. Hal ini bearti $94 \%$ dari pendapatan petani padi dipengaruhi oleh jumlah tangunggan, pendidikan, luas lahan, luas lahan, jumlah produksi, biaya modal, sedangkan sisanya $6 \%$ dijelaskan oleh faktor-faktor lain yang tidak dimasukan dalam model atau penelitian ini.

\section{Pengujian asumsi klasik}

Model yang dihasilkan sebelum digunakan untuk pengujian hipotesis, maka dilakukan pengujiam dengan asumsi klasik untuk Uji asumsi klasik dilakukan untuk meyakinkan bahwa model regresi yang digunakan adalah baik. 


\section{Uji normalitas}

Untuk mendeteksi apakah data terdistribusi normal atau tidak di dalam model penelitian menggunakan metode probability. Keputusan terdistribusi normal tidaknya residual secara sederhana dengan membandingkan nilai probability hitung dengan tingkat alpha 0,05 (5\%). Apabila probability hitung lebih besar dari 0,05 maka dapat disimpulkan bahwa residual terdistribusi normal. Berdasarkan gambar 5.1. Hasil pengolahan dapat dilihat nilai Nilai Probability hitung sebesar 0,09>0,05 sehingga dapat disimpulkan bahwa residual terdistribusi normal.

\section{Uji heteroskrdasitas}

Salah satu cara untuk mengetahui ada tidaknya heteroskedastisitas pada suatu model dapat menggunakan uji Breusch-Pagan-Godfrey. Keputusan terjadi atau tidaknya heteroskedastisitas pada model regresi linier adalah dengan melihat Nilai Prob. ChiSquare(5). Apabila nilai Prob. Chi-Square(5) lebih besar dari tingkat alpha 0,05 (5\%) artinya tidak terjadi heteroskedastisitas, sedangkan apabila nilai Prob. Chi-Square(5). lebih kecil dari dari tingkat alpha 0,05 (5\%) maka terjadi heteroskedastisitas. Dalam penelitian ini nilai Chi-Square(5) sebesar 0.1746 lebih besar dari tingkat alpha 0,05 (5\%) sehingga, dapat disimpulkan tidak terjadi gejala heroskedastisitas dalam model regresi.

\section{Uji multikolineritas}

Untuk mendeteksi adanya multikolinearitas dapat dilihat melalui variance inflation factor (VIF). Cara yang digunkan untuk mendeteksi ada atau tidaknya multikolinearitas adalah dengan melihat nilai tolerance dan VIFnya. Jika nilai VIF > 5 dan tolerance < 0,10 maka terjadi multikolinearitas.Berdasarkan hasil pengujian terlihat bahwa seluruh variabel independen yaitu jumlah tangunggan, pendidikan, luas lahan, jumlah produkasi dan biaya modal memiliki nilai VIF dibawah 5,0. Dengan demikian dapat dikatakan bahwa model yang terbentuk tidak terdapat adanya gejala multikolinearitas antar variabel independen dalam model regresi.

\section{Analisis SWOT}

Strategi peningkatan pendapatan petani padi di Kecamatan Gunung Tujuh Kabupaten Kerinci melalui analisis SWOT. Analisis SWOT terdiri dari 4 alternatif antara lain strategi S-O (strength opportunities), strategi S-T (strategi-threat), strategi W-O (weakness opportunities) yaitu metode analisis yang mengembangkan kekuatan, kelemagan, peluang dan ancaman, serta kendala-kendala yang harus dihadapi selama proses perencanaan.

Strategi yang dianggap memiliki prioritas tinggi, dan mendesak segera dilaksanakan tergantung pada letak kuadran dengan formulasi sumbu X dan Y, dimana sumbu X adalah EFAS (Peluang dan Ancaman ) dan sumbu Y adalah IFAS (Kekuatan-Kelemahan) dari hasil yang dinilai berdasarkan skoring pada tabel ditas. Maka hasilnya dapat dilihat pada Gambar 1.

Berdasarkan Gambar 1 menunjukkan letak kuadran diatas maka didapatlah titik kordinat untuk mentukan posisi strategi pada Gambar 5.2, maka dapat dijelaskan bahwa posisi strategi peningkatan pendapatan petani padi sawah di Kecamatan Gunung Tujuh Kabupaten Kerinci berada pada kuadran IV yang berarti posisi memiliki kelemahan dan ancaman yang besar bagi petani dalam meningkatkan pendapatan. Menurut Rangkuti (2015), menyatakan bahwa kuadran IV merupakan situasi yang tidak menguntungkan. 
Perusahaan menghadapi berbagai ancaman dan kelemahan internal. Strategi yang diterapkan adalah strategi agresif.). Strategi peningkatan pendapatan petani berada pada kuadran IV artinya Fokus strategi yang harus dilakukan yaitu mengoptimalkan kelemahan dan mengatasi berbagai ancaman. Matrik swot adalah matriks yang menginteraksi factor strategi internal dan ekternal. Tujuan dibuatnya matrik SWOT adalah untuk mengumpulkan sebanyak mungkin tindakan-tindakan atau strategi yang memungkinkan untuk digunakan dalam usaha.

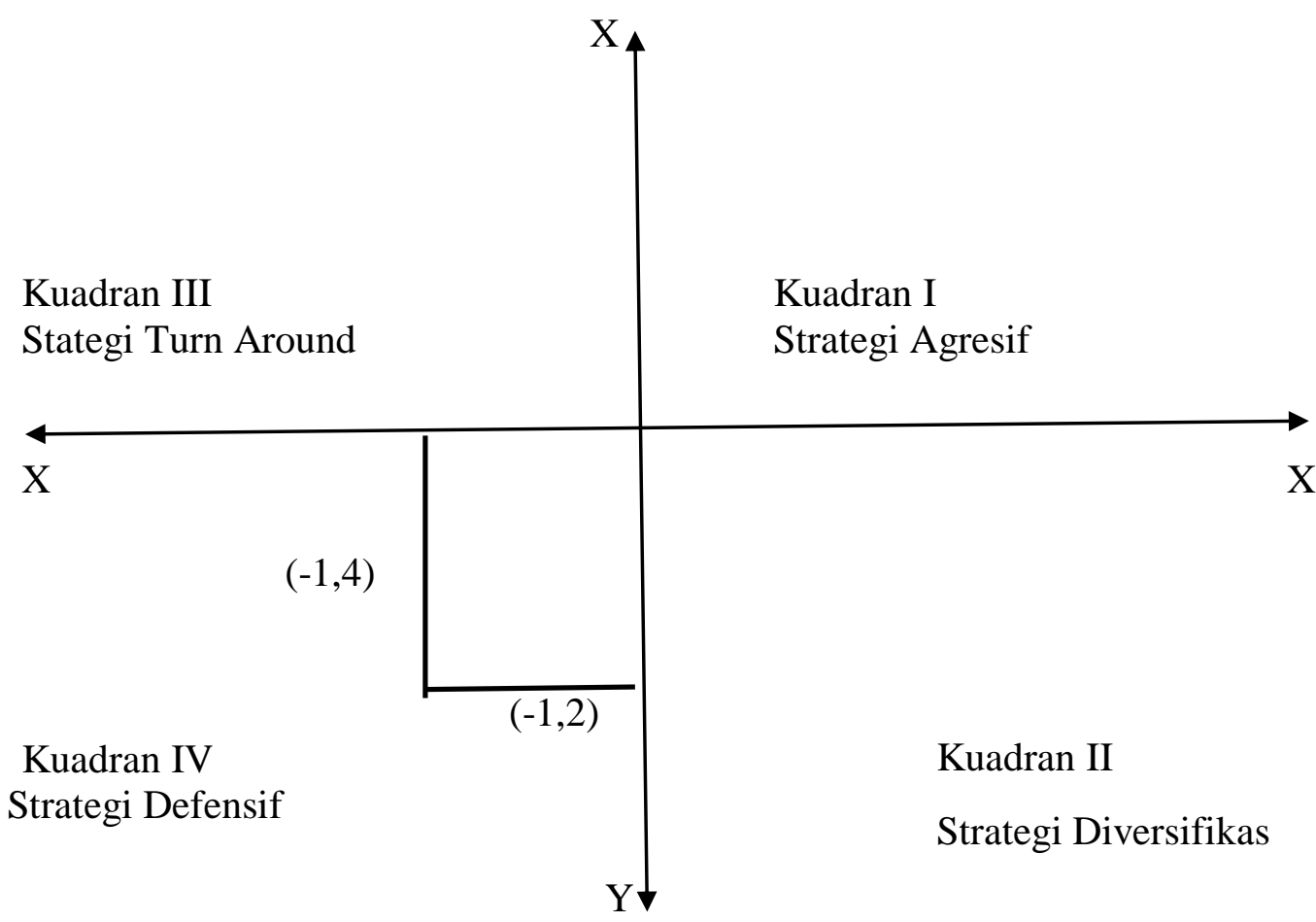

Gambar 1. Kuadran analisis SWOT

\section{Strategi S-O}

Strategi S-O atau strategi kekuatan-peluang merupakan strategi yang menggunakan kekuatan internal untuk memanfaatkan peluang ekternal. Berdasarkan kekuatan yang dimiliki petani padi dan kemampuan untuk meraih peluang dapat dirumuskan strategi antara lain: 1).Memanfaatkan ketersediaan subsidi sarana produksi dari pemerintah dan untuk semakin memacu motivasi petani dalam meningkatkan produksinya. 2).Memanfaatkan kondisi lahan yang sesuai untuk bertanam padi dan kemudahan ketersediaan kebutuhan bibit dan pupuk untuk memacu petani dalam meningkatkan produksi. 3).Mengoptimalkan terus penggunaan tingkat adopsi teknologi dalam pengolahan tanah dan memanfaatkan peluang dukungan dari pemerintah dalam pembangunan benteng air asin. untuk lebih meningkatan produksi.

\section{Strategi W-O}

Strategi W-O atau strategi kelemahan-peluang meruapakan strategi yang bertujuan untuk memperbaiki kelemahan internal dengan memanfaatkan peluang eksternal yang ada. 
Alternatif strategi yang didapat adalah sebagai berikut: 1).Memanfaatkan akses kredit dari perbankan sebagai modal untuk biaya input produksi, dengan adanya akses kredit diharapkan petaniakan lebih mudah mendapatkan pinjaman modal untuk mengatasi permasalahan kenaikan harga input produksi. 2).Mengoptimalkan penggunaan pupuk sesuai dosis yang tepat dan memanfaatkan penggunaan teknologi untuk meningkatkan produksi. 3).Peningkatan produksi dengan mengoptimalkan luas lahan yang sempit dan memanfaatkan program pemerintah dalam pembangunan benteng air asin untuk memacu peningkatan produksi petani.

\section{Strategi S-T}

Strategi S-T atau strategi kekuatan-ancaman adalah strategi yang menggunakan kekuatan internal untuk menghindari atau mengurangi ancaman eksernal yang dihadapi. Adapun strategi kekuatan-ancaman pendapatan petani padi antara lain: 1).Mengoptimalkan terus tingkat adopsi teknologi dan mengatasi permasalahan jumlah dan biaya tenaga kerja luar keluarga sehingga proses produksi bisa berjalan dengan baik. 2).Menggunakan pengalaman petani yang sudah sangat lama dalam bertani untuk mengatasi persoalan serangan hama dan penyakit agar proses produksi berjalan dengan baik. 3).Mengoptimalkan kondisi lahan yang sesuai untuk bertanam padi dan mengatasi perosalan musim (curah hujan) dengan mulai perbaikan pada sistem irigasi yang baik.

\section{Strategi W-T}

Strategi W-T atau strategi kelemahan-ancaman adalah strategi yang diarahkan untuk mengurangi kelemahan internal dan menghindari ancaman eksternal. Dari kelemahan dan ancaman yang dihadapi petani padi dapat dirumuskan alternative strategi antara lain: 1).Mengurangi alih fungsi lahan Penyusutan luas penggunaan Tanah Sawah terutama sawah irigasi teknis menyebabkan terjadinya kerugian materi (investasi) yang cukup besar menyebabkan terjadinya instabilitas di bidang pangan. Penyusutan luas tanah pertanian sawah, terjadi akibat perubahan penggunaan tanah pertanian (sawah) menjadi non pertanian seperti hunian/tempat tinggal/permukiman, industri, jasa dan lainnya. Maka perlu adanya kebijakan pemerintah tingkat Provinsi maupun tingkat Kabuapten/kota tentang Perlindungan Lahan Pertanian Pangan Berkelanjutan (LP2B) yang ditetapkan dalam Rencana Tata Ruang Wilayah. dengan selanjutnya kebijakan pemerintah memberi modal ke petani. 2).Mengiatkan kembali gapoktan dan memanfaatkan lembaga keuangan yang ada untuk modal usahatani. 3).Mengoptimalkan penggunaan pupuk dengan dosis yang tepat dan mengoptimalkan pengairan lahan sawah melalui irigasi agar tidak tergantung pada musim hujan.

\section{KESIMPULAN DAN SARAN}

\section{Kesimpulan}

Secara bersama-sama, besarnya pengaruh dari jumlah tangunggan, pendidikan, luas lahan, jumlah produksi dan biaya modal terhadap pendapatan petani padi di Kecmatan Gunung Tujuh Kabupaten Kerinci.besarnya kontibusi variabel jumlah tangunggan, pendidikan, luas lahan, jumlah produksi dan biaya modal dapat dilihat pada koefisien 
determinasi $\left(\mathrm{R}^{2}\right)$, hal ini bearti $94 \%$ dari pendapatan petani dipengaruhi oleh variabel bebas sedangkan sisanya $6 \%$ dipenngaruhi oleh faktor-faktor lainya tidak dimasukkan dalam model atau penlitian ini. Berdasarkan hasil regresi linear berganda dapat disimpulkan bahwa secara persial variabel luas lahan, jumlah produksi dan biaya modal berpengaruh signifikan terhadap pendapatan petani padi, sementara variabel jumlah tangunggan dan pendidikan tidak berpengaruh signifikan terhadap pendapatan petani padi di Kecamatan Gunung Tujuh Kabupaten Kerinci.Dari hasil matriks SWOT strategi yang dapat diterapkan di daerah penelitian untuk meningkatkan pendapatan petani padi sawah pada kuadran IV adalah Strategi Defensif (WT) artinya Fokus strategi yang harus dilakukan petani yaitu mengoptimalkan kelemahan untuk menghindari berbagai ancaman yaitu dengan menggiatkan kembali gapoktan, memanfaatkan lembaga keuangan yang ada, mengoptimalkan penggunaan pupuk dengan dosis yang tepat dan mengoptimalkan sumber pengairan irigasi untuk mengatasi persoalan musim hujan, meningkatkan kerja sama penyuluh dengan gabungan kelompok tani untuk mengatasi persoalan serangan hama dan penyakit.

\section{Saran}

Untuk meningkatkan pendapatan petani padi maka kebijakan yang dapat diambil yaitu program pemberian modal usaha program ini diperlukan untuk memberikan suntikan dana yang berupa pinjaman modal kepada petani. Selain itu dukungan program pemerintah dengan adanya kehadiran pemerintah untuk ikut mengatasi persoalan petani dilapangan, dengan adanya bantuan pemerintah dalam pembangunan sistem irigasi hal ini akan membantu petani untuk meningkatkan output produksi yang akan berdampak pula pada peningkatan petani padi.Kepada petani sebaiknya dapat mengoptimalkan sumberdaya yang dimiliki petani misalkan lahan, tenaga kerja, modal agar dapat menghindarkan berbagai ancaman pada usahataninya.

\section{DAFTAR PUSTAKA}

Abd. Rahim, dan Hastuti. (2008). Pengantar, Teori dan Kasus Ekonomika Pertanian. Penebar Swadaya: Jakarta.

Algifari.(2003).Statistika Induktif untuk Ekonmi dan Bisnis.AM YKPN:Yogyakarta Amir, Amri, dan Junaidi.(2009) Metodologi Penelitian dan Penerapan. IPB Press: Bogor Arifin. (2005). Teori Keuangan dan Pasar Modal. Ekosinia:Yogyakarta

Augusty, Ferdinand. (2006). Metode Penelitian Manajemen: Pedoman Penelitian untuk Skripsi, Tesis dan Disertai Ilmu Manajemen. Universitas Diponegoro: Semarang

Boediono, (2002). Ekonomi Makro: Seri Sinopsis Pengantar Ilmu Ekonomi No.1 Edisi 2. BPEE: Yogyakarta

Daniel, Moehar. (2004). Pengantar Ekonomi Pertanian. Bumi Aksara: Jakarta.

Fathorrozi,(2003). Teori Ekonomi Mikro : Salemba Empat: Jakarta.

Ghozali.(2006). Analisis Multivariat dengan Program SPSS. Edisi ke-3. UNDIP: Semarang.

Hasan, M. Iqbal. (2002). Pokok-pokok Materi Metodologi Penelitian dan Aplikasinya, Ghalia Indonesia: Bogor 
Hastuti,D Delis,A., \& Rosmeli. (2018). Pengembangan Komoditas Kelapa Sawit dan Karet serta Dampaknya Terhadap Pendapatan Petani di Kecamatan Pelepat Ilir, Jurnal Sains Sosio Humaniora, 2 (2), 92-104

Junaidi, J., Yulmardi, Y., \& Hardiani, H. (2020). Food Crops-Based And HorticultureBased Villages Potential As Growth Center Villages In Jambi Province, Indonesia, Journal of Critical Reviews, 7(9), 514 - 519

Kotler, Philip; Armstrong, Garry. (2008). Prinsip-prinsip Pemasaran,Jilid 1, Erlangga: Jakarta.

Soekartawi. (2002). Analisis Usahtani. Universitas Indonesia: Jakarta

Soekartawi. (2003). Teori Ekonomi Produksi dengan Pokok Bahasan Analisis Cobb Douglas: Jakarta :

Sukirno, Sadono. (2003). Pengantar Teori Mikro Ekonomi. PT. Salemba: Jakarta

Tarigan, Robinson. (2005). Ekonomi Regional-Teori dan Aplikasi Edisi Revisi. Bumi Aksara: Jakarta.

Todoro, Michael P. dan Stephen C.Smith. (2006). Pembangunan Ekonomi. Edisi ke 9. Erlangga: Jakarta 